\title{
Understanding interactions between urban development policies and GHG emissions: A case study in Stockholm Region
}

\author{
Haozhi Pan, Jessica Page, Le Zhang, Cong Cong, \\ Carla Ferreira, Elisie Jonsson, Helena Näsström, Georgia Destouni, \\ Brian Deal, Zahra Kalantari $(\mathbb{D}$
}

Received: 10 June 2019/Revised: 26 August 2019/Accepted: 31 October 2019/Published online: 20 November 2019

\begin{abstract}
Human-induced urban growth and sprawl have implications for greenhouse gas (GHG) emissions that may not be included in conventional GHG accounting methods. Improved understanding of this issue requires use of interactive, spatial-explicit social-ecological systems modeling. This paper develops a comprehensive approach to modeling GHG emissions from urban developments, considering Stockholm County, Sweden as a case study. GHG projections to 2040 with a social-ecological system model yield overall greater emissions than simple extrapolations in official climate action planning. The most pronounced difference in emissions (39\% higher) from energy use single-residence buildings resulting from urban sprawl. And this difference is not accounted for in the simple extrapolations. Scenario results indicate that a zoning policy, restricting urban development in certain areas, can mitigate $72 \%$ of the total emission effects of the model-projected urban sprawl. The study outcomes include a decision support interface for communicating results and policy implications with policymakers.
\end{abstract}

Keywords Climate change - Greenhouse gas emissions · Land-use change - Planning support system .

Social-ecological system $\cdot$ Stockholm

\section{INTRODUCTION}

Understanding the role of human-driven land-use changes in climate change is important for our ability to select effective and efficient mitigation and adaptation strategies

Electronic supplementary material The online version of this article (https://doi.org/10.1007/s13280-019-01290-y) contains supplementary material, which is available to authorized users.
(Bierwagen et al. 2010). Interactive effects of climate and land-use changes affect social and ecological systems, and provision of ecosystem services by the latter (Destouni et al. 2013; Seung-Hwan et al. 2013; Pan et al. 2019a). Urbanization is an essential part of human-driven land-use change, and its impacts need to be considered in regional climate modeling ( $\mathrm{Hu}$ et al. 2015). For example, Wilson and Weng (2011) show important soil and water implications for the Midwestern US when accounting for urbanized land use (impervious surfaces) in an integrated downscaled climate model.

Greenhouse gas (GHG) emissions and carbon sinks associated with urbanization are relatively well studied (Lubowski et al. 2006; Searchinger et al. 2008; Larsen and Hertwich 2010; Han et al. 2017). For example, Han et al. (2017) found significant increases in carbon emission sources and simultaneous loss of carbon sinks associated with fast urbanization in the Yangtze River Delta, China. Lubowski et al. (2006) model land uses in the contiguous US and suggest that future climate strategies need to consider forest-based carbon sequestration. Searchinger et al. (2008) use a worldwide agricultural model to estimate emissions from land-use change and show that cropland conversion for biofuels nearly doubles greenhouse emissions over 30 years in California. Larsen and Hertwich (2010) calculate the carbon footprint for 429 Norwegian municipalities and show that it changes significantly depending on municipality size and wealth level. Urban planning and policy tools are needed to identify and efficiently mitigate land-use changes associated with urbanization that pose major climate and environmental risks (Hobbs et al. 2016; Deal et al. 2017a; Pan et al. 2018b). Hobbs et al. (2016) present a regionally calibrated model for South Australia that collects new information to facilitate better decisions in regional land-use planning for 
reforestation and carbon sequestration. Recent progress in methods of emission accounting and policy analysis includes climate and ecosystem scenarios with implications for future urban land-use patterns (Pan et al. 2018a). Spatial-explicit assessments of the climate impacts and feedbacks of urbanization and associated land-use changes can provide substantial policy support in selecting priority areas for emission reductions (Pielke et al. 2002).

Models that capture interactive effects and feedbacks between climate and land-use/cover changes at high spatial resolution (finer than 100-m resolution) and over a mid- to long-term (such as future 30 years) temporal horizon can improve representation and capture of climate impacts on human social systems and human reactions (Bierwagen et al. 2010; Pan et al. 2019b). This can improve understanding and projection of future outcomes and impacts and inform strategies for GHG emission mitigation and adaptation (Pan et al. 2018b). Moreover, urban growth is often associated with increased energy use and associated GHG emissions (Chau et al. 2015; Kraucunas et al. 2015; Nejat et al. 2015; Gren et al. 2019). Change in urban form, through land-use change, also has transportation implications and can significantly influence travel demand (Hankey and Marshall 2010). Comprehensive social-ecological assessment of urban land uses and GHG emissions thus needs to incorporate and couple multiple economic, land use, transportation, climate, and other environmental factors (Bercht and Wijermans 2019; Carrière 2019; Ehrich et al. 2019; Valencia et al. 2019).

Besides increasing energy use and associated GHG emissions, urbanization is likely to simultaneously reduce carbon sinks, thus exacerbating climate change impacts. Climate change can in turn affect urban development decisions. For example, increased (or decreased) rainfall or flood risk can affect the expected economic efficiency of land development, thereby limiting the location and configuration of new urban developments (Deng et al. 2013). Deng et al. (2013) explore such interactions through regional climate modeling examining how social activities may be exposed to extreme climate events. Overall, climate and land-use modeling need to account for multiple social and ecological system interactions and feedbacks (such as climate impacts on human socio-economic activities, and human reactions that change emission patterns and volumes), in order to provide accurate and comprehensive scenario analysis to support relevant policy decisions.

In this study, we have developed and applied a processbased coupled social-ecological modeling approach to identify the complex interactions, and their effects and feedbacks, between urbanization and associated land-use changes and climate change. The model builds on existing approaches for constructing interactive and policy-driven scenarios of changes in (i) land use and (ii) GHG emissions. The modeling approach is applied to Stockholm County, Sweden. This was selected as case study since the region has high demand for urban growth due to projected increases of over $30 \%$ in population and employment from 2014 to 2040 (Tillväxt och regionplaneförvaltningen, TRF 2017). Such growth can induce high levels of associated GHG emissions. The major city in the region, Stockholm, the Swedish capital, is also a pioneer in climate action planning and has the planning capacity to use policy instruments to mitigate future emissions (Stockholm City 2016). The case study addresses the following main research questions: What are the aggregated climate impacts (focusing on GHG emissions and carbon sink losses) of urban land-use changes associated with building and transportation developments? Can improved ability to identify high-emission areas affect the design of climate change mitigation strategies, by appropriately restricting land development to achieve GHG emission goals?

Modeling of social-ecological processes and system feedbacks is necessary to answer these questions and test policy alternatives. Such modeling can also lead to further research developments and advances in knowledge of socio-economic interactions with climate and environmental changes through land-use changes. The methodology developed and applied in this study can be used for reevaluation of baseline emission scenarios, based on more realistic accounting of urban land-use effects and feedbacks.

\section{MATERIALS AND METHODS}

\section{Study area and data}

Stockholm County is the largest metropolitan region in Sweden. It includes the Swedish capital Stockholm, and the Stockholm Archipelago, which extends out into the Baltic Sea (Fig. 1). Stockholm County is located in the boreonemoral mixed-forest biome (Elmhagen et al. 2015) and its landscape includes urban areas (approximately 35\% of total regional area), urban green spaces $(7 \%)$, open water (both lakes and sea, 23\%), coniferous (24\%) and mixed (coniferous/deciduous, 4\%) forests, and arable land (7\%) (Goldenberg et al. 2017).

The Stockholm region has recently experienced major population growth. In 2018, 2315612 people lived in Stockholm County, representing $22.3 \%$ of Sweden's total population (TRF 2017). According to the regional planning office, TRF, the population of Stockholm County is expected to grow by nearly 30\% from 2014 to 2040, to around 2800000 inhabitants (TRF 2017). The region aims to be a worldwide leader in reducing GHG emissions, with the City of Stockholm having committed to being fossil 

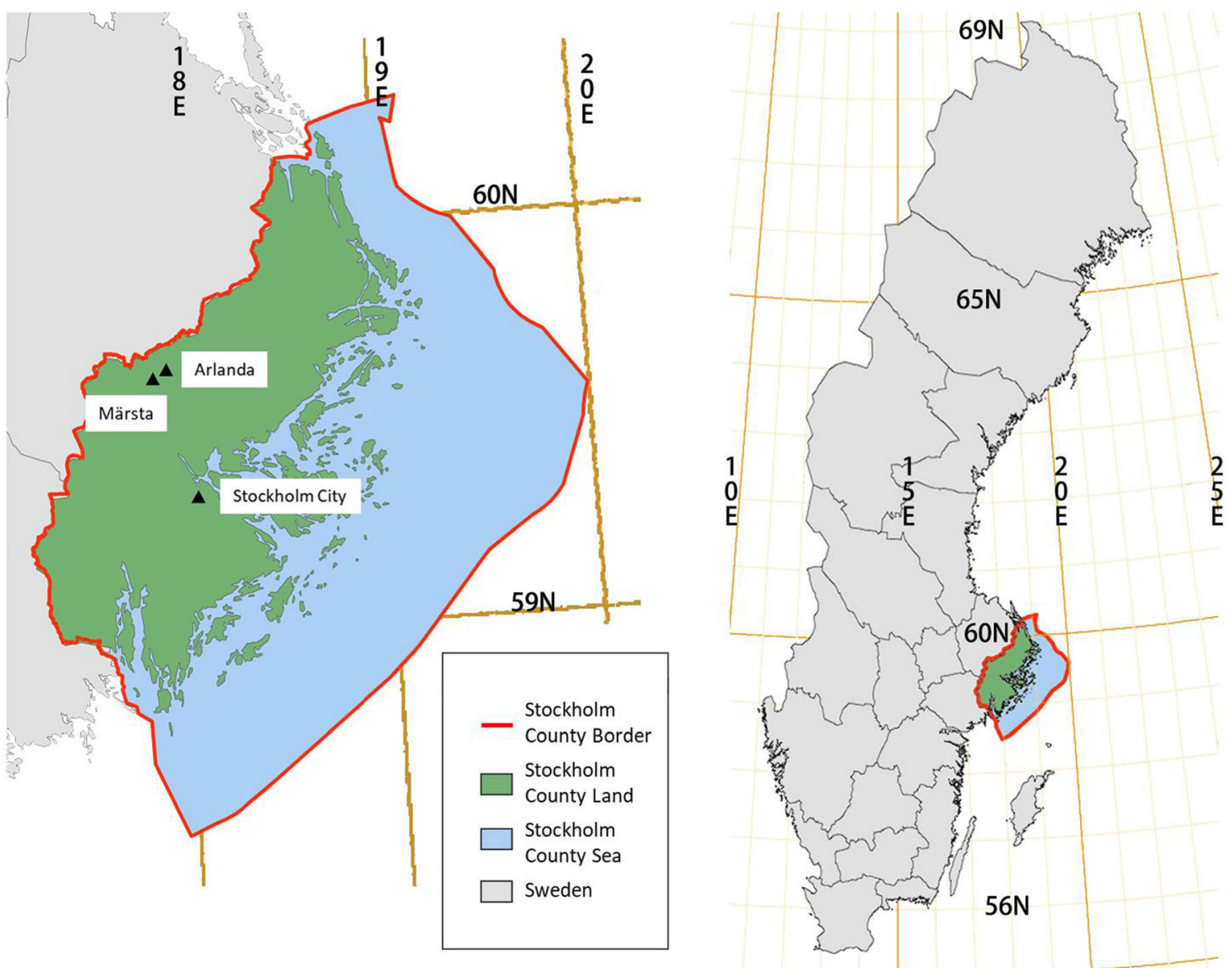

Fig. 1 Stockholm County (green area, left map), located in the mid-eastern region (green area, right map) of Sweden

fuel free by 2050 (a deadline recently brought forward to 2040), based on its Strategy for a fossil-fuel free Stockholm (Strategy 2040) (Stockholm City 2016).

The emission quantifications from Strategy 2040 are used and adapted for the modeling scope of this paper. Geographically, we model Stockholm County, which is a larger area than Stockholm City and its vicinity (as the focus of Strategy 2040), in order to also capture GHG emissions from the incoming-outgoing transportation of the main urban area in the region. The transportation emissions in the larger geography are obtained from Stockholm County's climate planning document (TRF 2018). For the emission scope of this paper, we also model land-use development beyond Stockholm City in order to estimate future emission growth in energy use of buildings (not considering the building manufacturing activities). Furthermore, this study accounts only for road and rail passenger vehicles in the transportation emissions. Adapted from Strategy 2040, we thus consider total emissions for Stockholm City of 3460000 tons of carbon dioxide equivalents $\left(\mathrm{CO}_{2} \mathrm{e}\right)$ for year 2014. Energy use in buildings contributes 1600000 tons and road and rail passenger travels contribute 1860000 tons of $\mathrm{CO}_{2} \mathrm{e}$ to these total emissions.

Beyond Stockholm City that, with roughly 1 million inhabitants, is the core urban area of Stockholm County, the present analysis also focuses on three northern suburban municipalities that are projected to host most of the future urban growth demand (TRF 2017). These are the Upplands-Bro Municipality (major growth in the Brunna area), with population of around 25000 in 2015 and a substantial proportion of agricultural land; the Vallentuna Municipality (major growth in the Brottby area), with population of around 30000 in 2015 and many singlefamily houses in high-quality natural amenities; and the Sigtuna Municipality (main growth associated with businesses relating to Arlanda International Airport in Märsta), with around 45000 inhabitants in 2015; the data and statistics for these municipalities are obtained from Statistics Sweden (2018).

Data for the overall Stockholm County case include existing features of the region, in a digital terrain model (DEM) with $30 \mathrm{~m} \times 30 \mathrm{~m}$ resolution, and existing population and job locations, land uses, roads, and public 
transport networks. These data have been provided by TRF, the Regional Development and Planning Department at Stockholm County Council. Land-use data are compiled from Urban Atlas (SE001L1_STOCKHOLM _UA2012) data and updated by Corine Land Cover (CLC European seamless vector database version 18_5) data to the land use of 2014. Data on planned future developments are obtained from the Regional Development Plan for the Stockholm County for 2050 (Regional Utvecklingsplan För Stockholmsregionen, RUFS 2050, TRF 2017). The future development data include planned road and public transport developments, "no-growth" zones (such as protected natural areas where no development is allowed), development areas, types of developments, development priorities, and demographic projections for the period 2015-2040. Base year data for 2014 from Strategy 2040, such as GHG emissions and total energy usage, are used as inputs in modeling.

\section{Framework for social-ecological process modeling and integration in policy decision support}

An integrated modeling framework is proposed and used here to investigate the regional GHG emissions within a dynamic urbanization context, and thus assess the impact of policy scenarios. The framework is the result of a multidisciplinary collaboration between scientists and stakeholders. It includes (1) complex models for land use, GHG emissions, and policy scenarios, and (2) a pathway for transferring multidisciplinary modeling expertise into useful policy practices, through comprehensive modeling accounting for feedbacks (Fig. 2a).

In the coupled system model, land-use scenarios are not static assumptions, but are based on a dynamic complex urban systems model that links socio-economic policy scenarios, land-use decisions, and associated GHG emission impacts. The physical availability of land for commercial and residential developments is forecast via bottom-up land-use change probabilities. This modeling approach requires integration and justification of both human (socio-economic and land-use policies) and ecological (GHG emissions associated with human activities that have global climate impacts) processes. The coupled model provides a process-based understanding of GHG emissions associated with urbanization and human-driven land-use changes, through assessment of carbon sink losses, emissions from new residential and commercial buildings, and transportation emissions associated with urban sprawl. It allows the environmental impact of various policies to be tested, and therefore leads to more informed decisions. The iterative and interactive modeling process is illustrated in Fig. $2 b$.

\section{Land-use and impact modeling}

\section{Land-use change model for complex urban systems}

In the proposed framework, as in other recent relevant modeling approaches for the Stockholm region (Kalantari et al. 2014, 2019; Pan et al. 2018b), the Land-Use Evolution and Impact Assessment Model (LEAM) is used to forecast scenarios of land-use changes in the study region. In LEAM, the land-use transformation potential of individual cells is evaluated by explicitly quantifying the forces (drivers) that contribute to change. Knowledge and account of the causal mechanisms of change provides local decision makers with the opportunity to test policy and investment choices and is a critical component for completing scenario planning exercises. Driver sub-models are locally dependent and derived through both analysis and local stakeholder interaction. An open architecture and modular design facilitates incorporation of additional local drivers, which are needed to improve the explanatory power of the model. A connectivity-based approach is used to measure city and employment centers for current land-use cells, and the outcome is used to identify highly probable re-development areas among existing developed land. Probability maps of future commercial and residential growth are built based on calibration. Future land-use allocations are subject to probability maps and population/employment growth projection based on scenarios identified. Details of LEAM calibration, validation, and variable specifications are documented in Supplementary Materials (S1).

\section{Carbon sink assessment}

In order to assess how future urban development and landuse change affect carbon sinks in Stockholm, driven by policy scenarios, social-ecological processes need to be coupled. This allows land cover conversions to be located from the urban growth process. It also allows associated carbon sink losses to be calculated based on the number of land cover cells $(30 \mathrm{~m} \times 30 \mathrm{~m}$ scale $)$ originally representing high-value carbon sinks (such as wetlands and forests with trees of young ages) that are converted into urban built-up areas (residential or commercial cells). We have created a carbon sink map of the study region based on the latest available land-use map (TRF 2017), considering six classes: forest, shrubs, grass, cultivated crops, pasture, and wetlands (including both woody wetlands and herbaceous wetlands). Within forest areas, carbon sink values in the model are assigned considering different vegetation types and ages, given the carbon sequestration potential of (i) young and productive forests, and (ii) established or naturally occurring forests. Forest age and type data are obtained from Copernicus Forests Dominant 

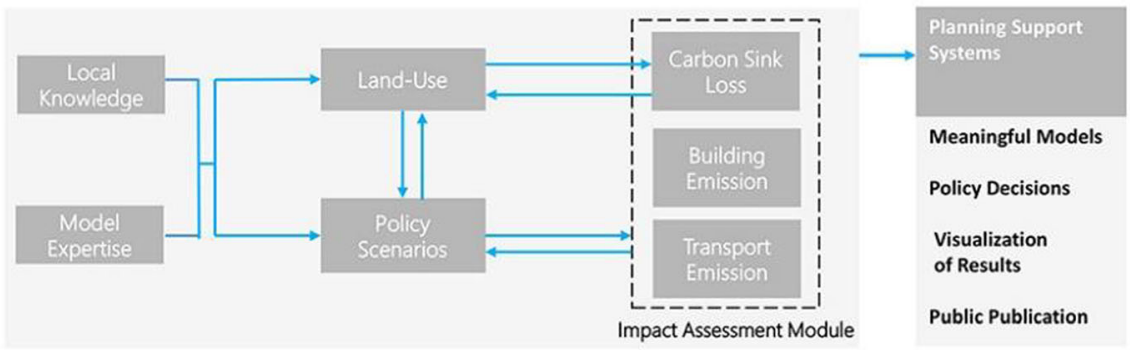

Path from Expert and local Knowledge to Policy Decision Support

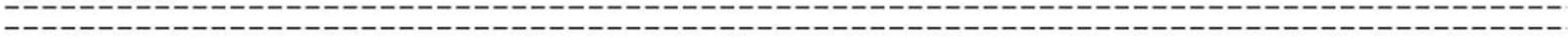

Loop between models

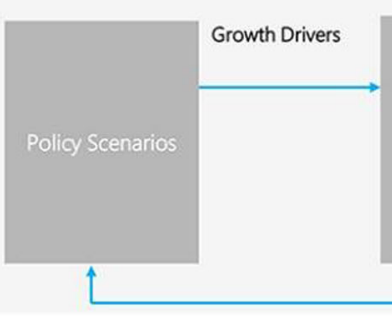

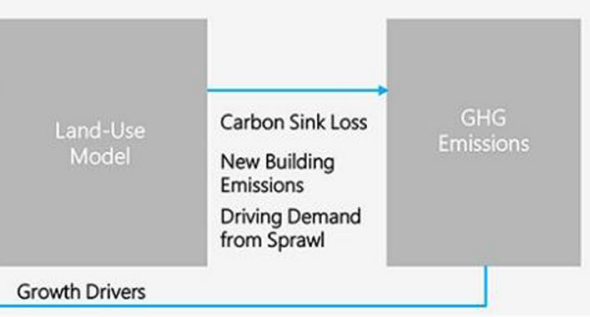

(a)

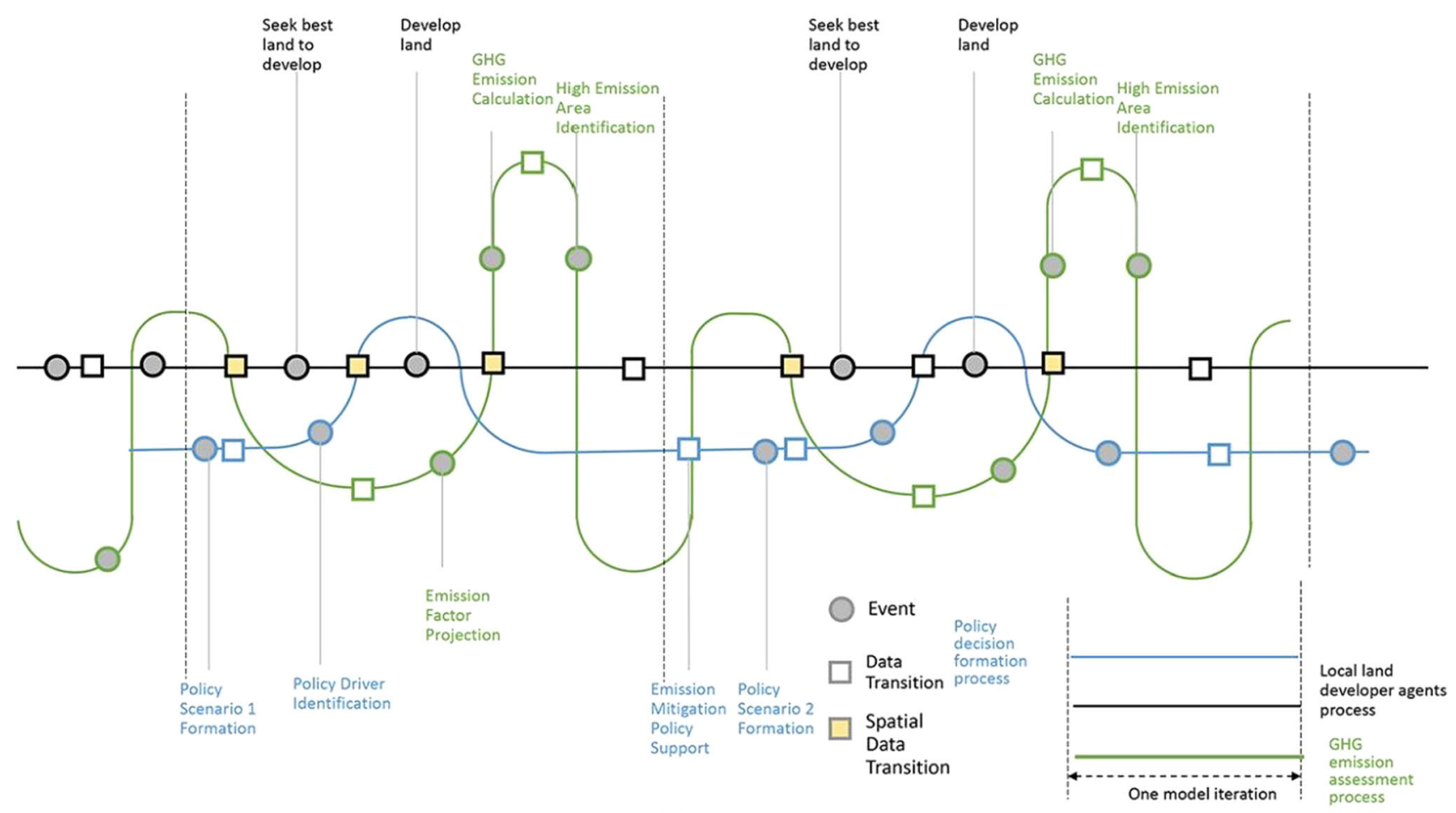

(b)

Fig. 2 a Framework for social-ecological process and system modeling and pathway to policy decision support and $\mathbf{b}$ processes and feedbacks of coupled policy scenario, land use, and GHG emission assessment. Event means environmental changes (such as change of total carbon sink values from land-use change) or human actions in the social-ecological model (such as policy reactions to emissions surpassing certain amount) 
Leaf Type (DLT-2015-20m). Details of carbon sink mapping are provided in Supplementary Materials S1.

\section{Assessment of emissions from residential and commercial buildings}

One of the major sources of carbon emissions associated with urbanization is energy use in buildings and associated commercial activities. In most current climate planning practices (including Strategy 2040), demand for new building construction is extrapolated from official population and employment forecasts. The main variable determining building energy use is building standards, including their requirements for technological improvements (such as better insulation, more efficient heating and cooling system, occupancy control systems). One key socio-economic and spatial-related factor that has so far been overlooked in residential GHG emission forecasts of existing climate action plans is the consequence of low-density residential developments associated with urban sprawl. Song and Knaap (2004) and Irwin and Bockstael (2007) report an increased tendency to build single-family houses with urban sprawl, resulting in higher GHG emissions per capita. Spatial-explicit land-use simulations can pinpoint new residential and commercial developments for regions with historic density and development pattern information. For example, simulated new urban growth that occurs at the urban fringe or suburban areas is more likely to involve single-family houses and large manufacturing companies (Pan et al. 2019b). On the other hand, in-fill developments at the urban core are more likely to involve high-density apartments and offices. Integrating land-use simulation and local density information can improve estimation of future building energy use. Details of the methods used for building energy emission estimation are provided in Supplementary Materials S1.

\section{Assessment of transportation emissions}

Previous studies have found that vehicle kilometers traveled (VKT) in and through an urban area increase with population and employment growth, and that total driving demand is also closely related to the urban form (Ewing et al. 2008; Cervero and Murakami 2010). Low-density and sprawl development can drive and increase GHG emissions (Liu and Shen 2011).

In this study, associated transportation emissions for 2040 are calculated based on the LEAM forecast of urban expansion (including urban form), together with passengervehicle GHG emissions calculated using the linear population density function of Hankey and Marshall (2010). Detailed information is provided in Supplementary Materials $\mathrm{S} 1$.
One important advantage of spatial-explicit modeling of land-use development is that change in future urban form can be forecast, along with total growth. As a result, VKT can be better estimated based on the new urban form forecast. The impacts of transportation systems on future urban development can be more accurately predicted by combining VKT estimates and projections on vehicle and fuel technology.

\section{Policy scenario analysis}

As key human feedbacks in social-ecological systems, the model simulates local government reaction to potential GHG emissions as a LEAM "mitigation zoning" (MZ) scenario, comparing its emission outcomes to those of the Strategy 2040 baseline scenario, and the LEAM reference scenario. The key assumptions in each scenario are listed in Table 1 and described below. Note that all scenarios use the same population change (from 2163000 in 2014 to 2800000 in 2040) and employment growth projection (from 1150000 in 2014 to 1500000 in 2040). The difference between the scenarios is the urban growth patterns with the new growth and effects on GHG emissions.

To address feedbacks of human reaction to human-driven climate change, the social-ecological modeling approach uses dynamic (annual) information on GHG emissions to investigate the LEAM MZ policy scenario, as an example of mitigation/adaptation response measures in future urban developments. The key assumption in the MZ scenario is that policymakers have strong awareness of urban growth and land-use change interactions, and their associated generation of GHG emissions (spatial emission intensity), and make adaptive policy changes at 5-year intervals.

Table 1 Key scenario assumptions

\begin{tabular}{ll}
\hline Scenarios & Key assumptions \\
\hline $\begin{array}{l}\text { Baseline (Strategy } \\
\text { 2040) }\end{array}$ & $\begin{array}{c}\text { The 2040 GHG emissions is projected based on } \\
\text { the proportion projected population increase } \\
\text { based on Strategy 2040 (Stockholm City } \\
\text { 2016) }\end{array}$ \\
$\begin{array}{l}\text { The 2040 GHG emissions is simulated based on } \\
\text { Reference } \\
\text { (LEAM) } \\
\text { how new commercial and residential } \\
\text { development to host the growing population } \\
\text { would have implications on carbon sink, } \\
\text { building, and transportation energy use }\end{array}$ \\
$\begin{array}{l}\text { The 2040 GHG emissions is simulated based on } \\
\text { the reference (LEAM) model, while } \\
\text { residential and commercial growth that could } \\
\text { lead to high future GHG emissions are } \\
\text { designated as no-growth zones }\end{array}$ \\
\end{tabular}


The policy instrument considered in the model is the designation of special zones with restricted residential and commercial developments. Several types of special zones are identified and simulated by LEAM. The first type is future flood zones under expected climate change scenarios. This simulates policymakers' awareness of climate change impacts prompting them to actively adapt future development strategy for climate mitigation. In the second type, 2040 flooding zones are projected by a hydrological model (r.sim.water) and a hydrodynamic model (MIKE FLOOD) with LEAM land-use change inputs. This simulates policymakers' awareness of the necessity for climate adaptation. The third type is referred to as other no-growth zones, such as forest preserves, parks, and water bodies. Areas associated with high emission potential (such as large patches of forests occupied by urban development, regions far from urban cores, or single-family residence areas), flooding potential, or other types of restrictions are set as no-growth zones. As a result, residential and commercial developments are shifted to places with lower emission and flooding potential, although socio-economic attractiveness (measured by the LEAM probability map) may be slightly lower in those places.

Current GHG emission planning usually adopts energy (such as renewable energy), vehicle and building technology, or behavior-related policy to reduce future carbon emissions. In this study, we consider innovative spatial zoning, based on feedback from spatial-explicit model results, as an additional policy instrument available for policy makers to mitigate GHG emissions, with an assumed 5-year planning cycle for policy implementation and adjustment. GHG emissions from this spatial zoning policy scenario are compared with those in the Strategy 2040 baseline and the LEAM reference scenarios. Full details of the MZ policy scenario and feedback modeling are provided in Supplementary Materials S1.

\section{RESULTS}

\section{Projected land-use change and urban expansion}

The projected urban expansion is shown in Fig. 3. An area of $1.40 \mathrm{~km}^{2}$ of single-family homes and $10.82 \mathrm{~km}^{2}$ of multi-family homes can be expected to be built in Stockholm region by 2040. According to Strategy 2040, current residents live in about $34 \mathrm{~km}^{2}$ of total residential building stocks of different types. Total new development $\left(12.22 \mathrm{~km}^{2}\right)$ is expected to host about $30 \%$ of the new population (about 600 000) in Stockholm. Thus, the simulated residential developments have on average similar number of residents per area as the current housing stock. Most of the new development is expected to occur in the existing urban center, with some developments also occurring in sub-centers, including the Märsta and Arlanda Airport regions. The results show that Stockholm has a lower tendency for sprawl development than many other cities around the world, especially in North America (Pan et al. 2019b). Nevertheless, the rural developments in Märsta and other northern suburbs may be associated with higher than expected residential and transportation energy use.

\section{Projected carbon sinks}

In the LEAM reference scenario, the changes from current to future land-use developments lead to carbon sink loss at a peak annual rate of $20.3 \mathrm{KT} \mathrm{CO}_{2} \mathrm{e}$ in 2040. This is equivalent to loss of $2.4 \%$ of the 2014 total carbon storage potential $\left(\mathrm{CO}_{2} \mathrm{e} /\right.$ year $)$ in the Stockholm region. Aggregating the carbon sink losses to their total cumulative sink value until 2040 (if they were not removed in the land-use developments) leads to a decrease in storage potential of around 2.3 $\mathrm{MT} \mathrm{CO}_{2} \mathrm{e}$.

\section{Projected GHG emissions}

In the LEAM reference scenario, the projected new buildings yield a total increase in residential energy use of $1.27 \mathrm{GWh} / \mathrm{m}^{2}$. Based on a similar assumption as in Strategy 2040 (31\% emission reduction in building energy use for new developments compared with current buildings), total annual GHG emissions of $2.83 \mathrm{MT} \mathrm{CO}_{2} \mathrm{e}$ are expected by 2040 in the LEAM reference scenario, which is $39.4 \%$ more than in the Strategy 2040 baseline scenario. Hence, urban sprawl with more single-family developments makes an essential difference and must be accounted for in projections of building-related GHG emissions.

In 2011, total passenger VKT of cars and public transit in Stockholm County was around 9.82 billion $\mathrm{km} / \mathrm{year}$, generating GHG emissions of $0.53 \mathrm{MT} \mathrm{CO}_{2} \mathrm{e}$. In the LEAM reference scenario, the projected VKT for 2040 is 13.55 billion $\mathrm{km} / \mathrm{year}$, implying emissions of $2.63 \mathrm{MT}$ $\mathrm{CO}_{2} \mathrm{e} /$ year, if public network expansion is assumed to develop at the same rate as the VKT growth. Thus passenger-vehicle emissions may almost double if no public transportation or fuel economy measures are taken to mitigate the growth in travel demand. This estimate of the LEAM reference scenario implies (13.8\%) lower transportation emissions than in the baseline scenario of Strategy 2040 (3.05 MT $\mathrm{CO}_{2} \mathrm{e} /$ year). However, it is then important that public transportation networks are expanded in line with the overall increasing transportation needs, in order to mitigate the growth in transportation emissions associated with the urban land-use growth. 


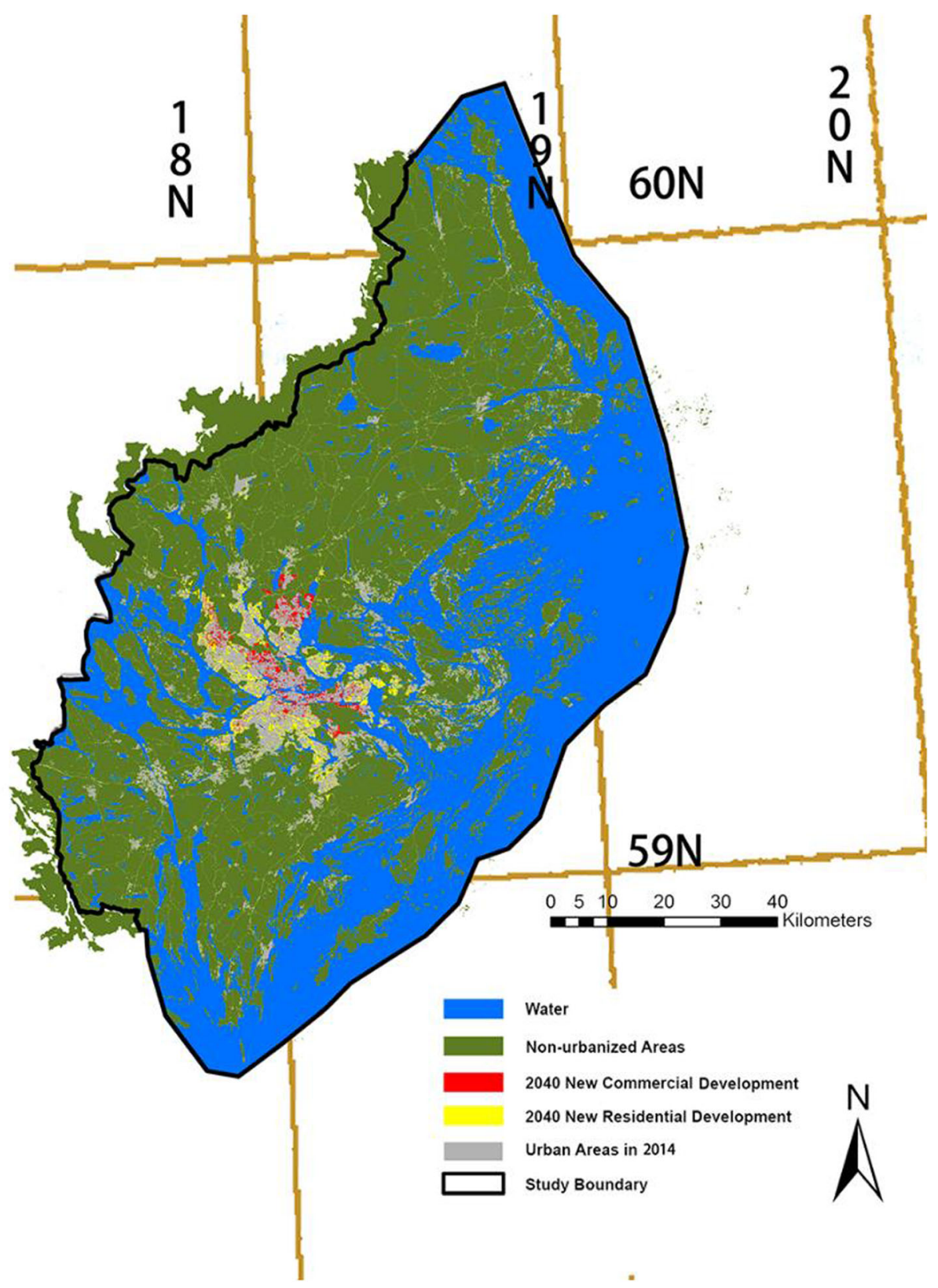

Fig. 3 Land-use change projection in the LEAM reference scenario for the 2014-2040 period in the Stockholm region

In total, the LEAM reference scenario emissions from both energy use in buildings and associated transportation, in combination with the carbon sink losses, are 5.48 MT $\mathrm{CO}_{2} \mathrm{e} /$ year. These are $7.9 \%$ higher than the extrapolated emissions of 5.08 MT $\mathrm{CO}_{2} \mathrm{e} / \mathrm{year}$ in the Strategy 2040 baseline scenario. Even though this total difference is relatively small, it is important that it indicates the simple extrapolation as non-conservative, i.e., tending to underestimate rather than overestimate future total emissions.

\section{Mitigation zoning policy scenario}

The no-growth zones with restricted residential and commercial developments in the LEAM MZ scenario for 2040 are shown in Fig. 4.

Figure 5 further shows the new development pattern in the LEAM MZ scenario, highlighting areas to which developments are relocated in comparison with the LEAM reference scenario. Two types of developments in the 


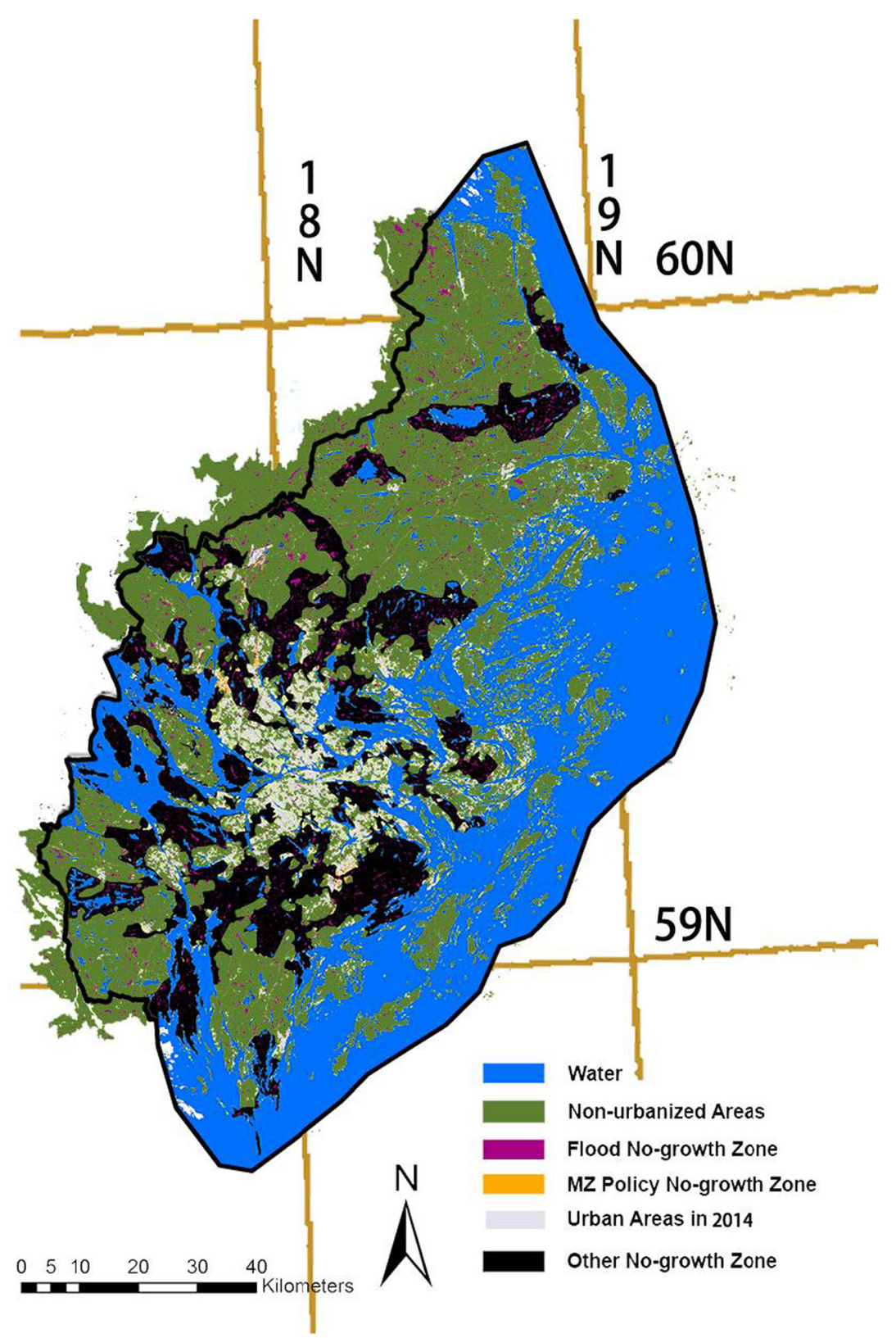

Fig. 4 No-growth areas in the LEAM mitigation zoning (MZ) scenario for the Stockholm region by 2040

reference scenario do not occur in the MZ scenario (Fig. 5): (i) urban developments in forest areas in the central city fringe, due to high carbon sink potential there, and (ii) urban developments in the Märsta and Arlanda Airport regions, which are limited due to their high emission potential as they generate major demand for travel/transportation to other developed areas in the city. Development in the MZ scenario is instead shifted to the Brunna and east Brottby urban clusters, which have relatively low carbon sink potential and require only about $70 \%$ of the travel time and distance to the main urban core compared with the Märsta and Arlanda Airport regions.
Comparison of projected carbon sink losses and GHG emissions in the LEAM reference and MZ scenarios (Table 2) shows that in the MZ scenario: (i) carbon sink losses are reduced by $64.5 \%$, to $7.20 \mathrm{KT} \mathrm{CO}_{2} \mathrm{e} /$ year (from 0.02 to $0.01 \mathrm{MT} \mathrm{CO}_{2} \mathrm{e} /$ year if rounded as in Table 2), (ii) transportation emissions are reduced by $6.7 \%$, to $2.72 \mathrm{MT}$ $\mathrm{CO}_{2} \mathrm{e} / \mathrm{year}$, and (iii) building emissions are reduced by $3.7 \%$, to $2.46 \mathrm{MT} \mathrm{CO}_{2} \mathrm{e} / \mathrm{year}$. This leads to a $5.3 \%$ reduction in total GHG emissions (including carbon sink losses), to 5.19 MT $\mathrm{CO}_{2} \mathrm{e} /$ year in the LEAM MZ scenario compared to the 5.48 MT $\mathrm{CO}_{2} \mathrm{e} /$ year in the LEAM reference scenario without a $\mathrm{MZ}$ policy. This emission decrease by $0.29 \mathrm{MT} \mathrm{CO}_{2} \mathrm{e}$ 


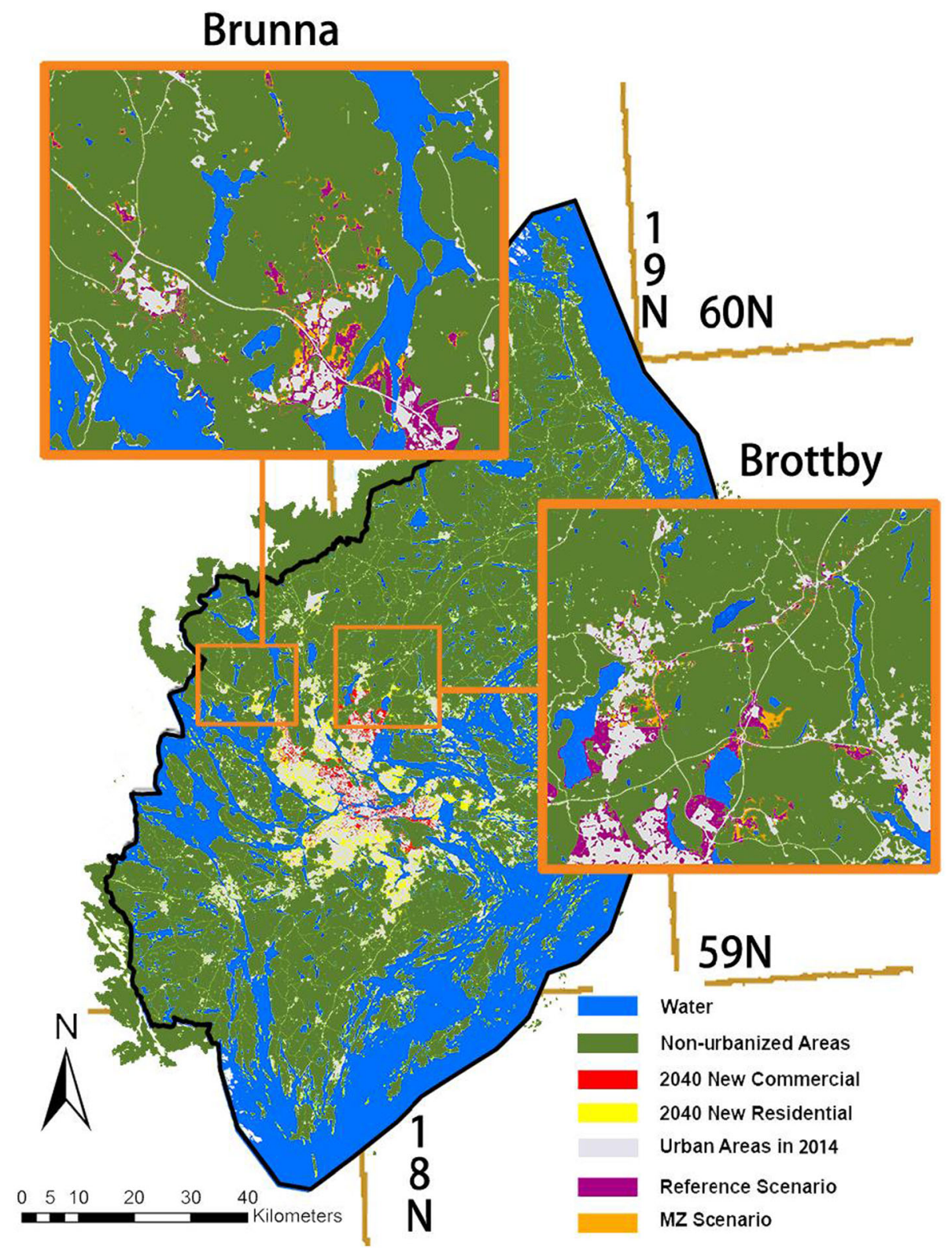

Fig. 5 Location of urban developments in the LEAM mitigation zoning (MZ) scenario for the Stockholm region by 2040. The Brunna and east Brottby urban clusters are highlighted because urban developments are largely shifted there in the MZ scenario

achieved by the MZ policy instrument corresponds to around $72.5 \%$ of the GHG emission increase caused by the urban growth and land-use changes (i.e., of the $0.4 \mathrm{MT} \mathrm{CO}_{2} \mathrm{e}$ difference between the 5.48 $\mathrm{MT} \mathrm{CO}_{2} \mathrm{e}$ emissions of the LEAM reference scenario and the $5.08 \mathrm{MT} \mathrm{CO}_{2}$ e emissions assumed in the baseline scenario of Strategy 2014). The LEAM MZ scenario still has higher total GHG emissions than the Strategy 2040 baseline scenario, because the urban growthinduced increases in GHG emissions cannot be addressed by urban growth management policies alone. Additional measures, such as technology improvements, building standards, and transportation policies, are needed to complement urban growth management in addressing the associated emission increases.

\section{DISCUSSION}

\section{GHG emissions driven by land-use changes and Strategy 2040 goals}

The 2040 GHG emissions estimated by the coupled socialecological system modeling in the LEAM reference scenario are $7.9 \%$ higher than those simply extrapolated from current trends in the Strategy 2040 baseline scenario 
Table 2 GHG emissions driven by carbon sink losses and new developments (building and transportation network) in (i) the existing condition (2014), when the Strategy 2040 plans are published, (ii) the "Strategy 2040 Baseline," based on current land-use trends, (iii) the "Reference Scenario," which integrates both socio-ecological process (LEAM) and GHG emission models; and (iv) the "Mitigation Zoning Scenario," assuming political strategies for spatial restrictions to new urban developments in 2040

\begin{tabular}{|c|c|c|c|c|}
\hline \multirow[t]{2}{*}{ Scenarios } & \multirow{2}{*}{$\begin{array}{l}\text { Carbon sink } \\
\text { loss (MT } \\
\mathrm{CO}_{2} \mathrm{e} / \text { year) }\end{array}$} & \multicolumn{2}{|c|}{$\begin{array}{l}\mathrm{GHG} \text { emissions }\left(\mathrm{MT} \mathrm{CO}_{2} \mathrm{e} /\right. \\
\text { year) }\end{array}$} & \multirow{2}{*}{$\begin{array}{l}\text { Total } \\
(\mathrm{MT} \\
\mathrm{CO}_{2} \mathrm{e} / \\
\text { year })\end{array}$} \\
\hline & & $\begin{array}{l}\text { Building } \\
\text { (excluding } \\
\text { manufacturing } \\
\text { activities) }\end{array}$ & $\begin{array}{l}\text { Road } \\
\text { passenger- } \\
\text { vehicle } \\
\text { transportation }\end{array}$ & \\
\hline $\begin{array}{l}2014 \\
\quad \text { Existing } \\
\text { conditions }\end{array}$ & $\begin{array}{l}\text { Not } \\
\quad \text { included }\end{array}$ & 1.60 & 1.86 & 3.46 \\
\hline $\begin{array}{l}\text { Baseline } \\
\quad \text { (Strategy } \\
2040)\end{array}$ & $\begin{array}{l}\text { Not } \\
\quad \text { included }\end{array}$ & 2.03 & 3.05 & 5.08 \\
\hline $\begin{array}{l}\text { Reference } \\
\text { (LEAM) }\end{array}$ & 0.02 & 2.83 & 2.63 & 5.48 \\
\hline $\begin{array}{l}\text { Mitigation } \\
\text { zoning } \\
\text { (LEAM) }\end{array}$ & 0.01 & 2.72 & 2.46 & 5.19 \\
\hline
\end{tabular}

(Table 2). The Strategy 2040 extrapolation is based on official population growth projections and past change trends in per capita emissions, while LEAM forecasts spatially explicit land-use changes to capture the future GHG emissions associated with such changes in urban form. While such changes may be relatively small in Stockholm City and County, they may be considerably larger in other urban regions, with the LEAM-based approach developed and used in this study being important for facilitating assessments and comparisons of such regional conditions.

In the Stockholm case study, the LEAM reference scenario emissions are higher than those in both the Strategy 2040 baseline scenario and the LEAM MZ scenario for three main reasons, with general relevance. (1) Urban expansion moves into occupying previous natural areas, resulting in loss of carbon sinks. (2) Urban sprawl takes place in suburban areas that traditionally favor singlefamily residence developments, resulting in higher per capita emissions from the energy use of buildings. (3) Urban sprawl also increases the per capita travel demand, resulting in relatively high per capita VKT and associated transportation GHG emissions.

The fact than GHG emissions are higher in the LEAM reference scenario than those extrapolated in the baseline scenario indicates the simple extrapolation method as nonconservative and rather tending to be insufficient for capturing the full future GHG emissions from urban expansion and associated land-use changes. Such simple extrapolation methods also are not readily useful for testing different policy and management scenarios (especially not spatially explicit ones) and may fail in guiding relevant, efficient measures for emission mitigation.

As an important example of spatially explicit policy instrument, the MZ scenario can specifically target reduction of urban growth in areas with high emission or high carbon sink potential. Although the GHG emission reductions relative to the reference scenario are less than $10 \%$ in the Stockholm case (Table 2), this may still be an essential mitigation contribution to the urban and regional spatial planning, extending and complementing the total set of policy instruments and measures required to attain the carbon-neutral goal of Strategy 2040.

For other parts of the world, Ewing and Hamidi (2015) present evidence that, e.g., in US cities, $9 \%$ of VKT could be reduced if compact growth strategies were adopted instead of urban sprawl. The potential to cut emissions in Stockholm is lower because this and other European cities have historically embraced a less sprawling pattern than US cities. However, spatial growth management policies may still be important for Stockholm to accommodate future population and employment growth while also achieving the region's and the city's ambitious climate and carbon neutrality goals.

\section{Relevance for policy implementation}

This study was performed together with stakeholders from Stockholm County. An important aspect of our integrated social-ecological modeling approach is the adequacy of information provided to support policymakers, such as the impacts of MZ policy. In an effort to facilitate such communication in the practical policy domain, a planning support system (PSS) was developed to operationalize the modeling work and provide its outcomes for further policy analysis. The PSS interface is available at http://portal. leam.illinois.edu/stockholm2017/ and the scenarios analyzed in this paper are available in Supplementary Materials S1. A screenshot of the PSS interface is shown in Fig. 6.

The development of the online PSS for Stockholm brings two major advantages to further research on climate action planning. First, it can be used to explore and show the consequences of different land-use development scenarios in tangible and objective ways that can challenge habitual ways of thinking and unsustainable development patterns (Deal et al. 2017b). The display of land-use development and assessment of resulting emissions in the PSS can help researchers and policymakers to better understand the costs associated with each development 


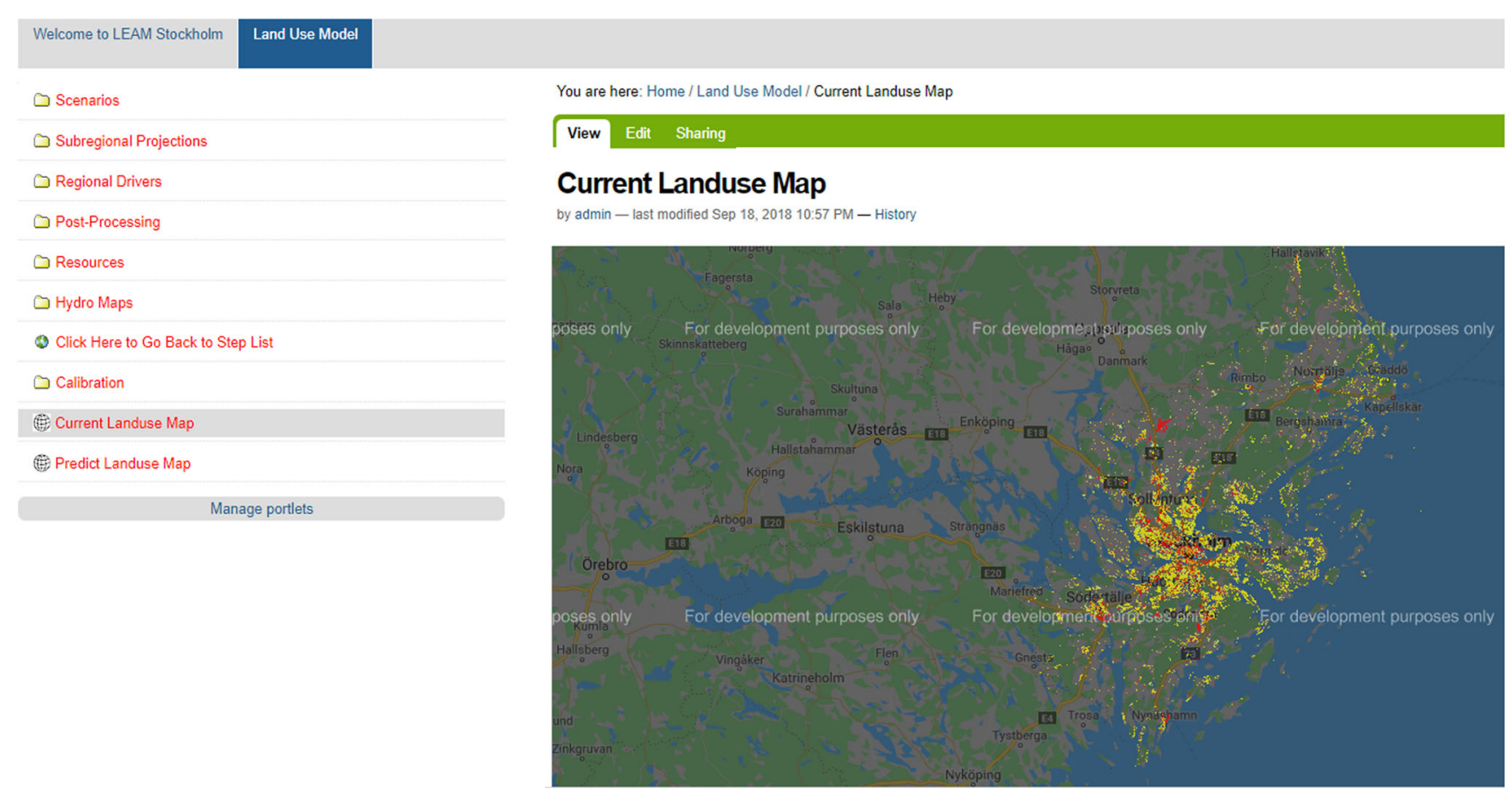

Fig. 6 Screenshot of the online LEAM planning support system (PSS) for Stockholm (http://portal.leam.illinois.edu/stockholm2017)

decision. The PSS can also enable "continuous planning" whereby data and models are continuously accessed, examined, and communicated, so that the success/failure pathways of alternative and complementary policies can be determined and re-assessed (Kalantari et al. 2017a, b, 2019; Pan and Deal 2019; Yang et al. 2019). The LEAM-PSS model can readily be updated as new land-use or census data, or new information on planning decisions and followup monitoring, become available.

The PSS can also be used to facilitate a mutual learning process on environmental sustainability among cities worldwide (Pan et al. 2018b). Stockholm is one of the pioneers in climate planning, and its deeper understanding of future urban growth and GHG emissions can be applied to other cities by replicating the online cloud-based PSS with a localization process. In order to effectively communicate with local stakeholders via the PSS interface, it is essential to build the model with local stakeholders, involving them in tuning model parameters and validating model results. The information shown to non-expert stakeholders should be easy to understand, such as visual maps of model forecasts of some policy scenarios or some readily understandable quantitative outcomes.

\section{CONCLUSIONS}

We present a social-ecological process and systems modeling framework for examining future GHG emissions of various urban development and growth scenarios. The Strategy 2040 of Stockholm City (2016) sets an overarching goal of net-zero GHG emissions by 2040 . Our results show that spatial urban growth and associated changes in land use, carbon sink decreases, and energy uses in buildings and for transportation pose additional challenges to the net-zero emissions goal, unaccounted for in the regional and city development planning. In particular, single-family housing developments associated with urban sprawl have the strongest emission impacts of all forms of urban development. Simulated feedback loops between impacts and policies can improve cause-effect evaluation and support understanding and quantification of alternative policy impacts, such as those of zoning policies that spatially restrict some urban developments. As such, these types of simulations can be an important instrument for GHG emission mitigation. A visualized interface of PSS can also facilitate communication among scientists, policymakers, and other stakeholders, and between cities worldwide willing to take part in mutual learning exercises to improve urban and climate action planning.

Several steps can be taken to extend this research. For example, the GHG emission assessment can be extended by including a human adaptation component to various aspects of climate change (such as flooding, drought, and other extreme events). A comparative modeling framework can improve and extend the current approach by further exploration of modeling assumptions across multiple cities with different development patterns and cultures, such as 
propensity for sprawl or local preferences for transportation modes.

Acknowledgements Open access funding provided by Stockholm University. The work is supported by funding from the Swedish Research Council Formas (grant number 2016-02045 and 2017-00608) and LS2018-0736 from Stockholm County (in Swedish: Stockholm läns landsting) and from the European Commission (project COASTAL, 773782). This work is also supported by the Portuguese Science and Technology Foundation, through the PostDoctoral Fellowship SFRH/BPD/120093/2016. We thank Michael Erman from Regeringskansliet (the cabinet office) for generation of new ideas.

Open Access This article is distributed under the terms of the Creative Commons Attribution 4.0 International License (http:// creativecommons.org/licenses/by/4.0/), which permits unrestricted use, distribution, and reproduction in any medium, provided you give appropriate credit to the original author(s) and the source, provide a link to the Creative Commons license, and indicate if changes were made.

\section{REFERENCES}

Bercht, A.L., and N. Wijermans. 2019. Mind the mind: How to effectively communicate about cognition in social-ecological systems research. Ambio 48: 590-604. https://doi.org/10.1007/ s13280-018-1099-7.

Bierwagen, B.G., D.M. Theobald, C.R. Pyke, A. Choate, P. Groth, J.V. Thomas, and P. Morefield. 2010. National housing and impervious surface scenarios for integrated climate impact assessments. Proceedings of the National Academy of Sciences of USA 107: 20887-20892.

Carrière, Y., Z.S. Brown, S.J. Downes, G. Gujar, G. Epstein, C. Omoto, N.P. Storer, D. Mota-Sanchez, et al. 2019. Governing evolution: A socioecological comparison of resistance management for insecticidal transgenic Bt crops among four countries. Ambio. https://doi.org/10.1007/s13280-019-01167-0.

Cervero, R., and J. Murakami. 2010. Effects of built environments on vehicle miles traveled: Evidence from 370 US urbanized areas. Environment and Planning A: Economy and Space 42: 400-418.

Chau, C., T. Leung, and W. Ng. 2015. A review on life cycle assessment, life cycle energy assessment and life cycle carbon emissions assessment on buildings. Applied Energy 143: 395-413.

Deal, B., H. Pan, S. Timm, and V. Pallathucheril. 2017a. The role of multidirectional temporal analysis in scenario planning exercises and Planning Support Systems. Computers, Environment and Urban Systems 64: 91-102.

Deal, B., H. Pan, V. Pallathucheril, and G. Fulton. 2017b. Urban resilience and planning support systems: The need for sentience. Journal of Urban Technology 24: 29-45.

Deng, X., C. Zhao, and H. Yan. 2013. Systematic modeling of impacts of land use and land cover changes on regional climate: A review. Advances in Meteorology. https://doi.org/10.1155/ 2013/317678.

Destouni, G., F. Jaramillo, and C. Prieto. 2013. Hydroclimatic shifts driven by human water use for food and energy production. Nature Climate Change 3: 213.

Ehrich, D., A.E. Thuestad, H. Tømmervik, P. Fauchald, and V.H. Hausner. 2019. Local land use associated with socio-economic development in six Arctic regions. Ambio 48: 649-660. https:// doi.org/10.1007/s13280-018-1095-y.

Elmhagen, B., G. Destouni, A. Angerbjörn, S. Borgström, E. Boyd, S.A.O. Cousins, L. Dalén, J. Ehrlén, et al. 2015. Interacting effects of change in climate, human population, land use, and water use on biodiversity and ecosystem services. Ecology and Society 20: 23. https://www.ecologyandsociety.org/vol20/iss1/ art23/. Accessed 12 Nov 2019.

Ewing, R., and S. Hamidi. 2015. Compactness versus sprawl: A review of recent evidence from the United States. Journal of Planning Literature 30: 413-432.

Ewing, R., T. Schmid, R. Killingsworth, A. Zlot, and S. Raudenbush. 2008. Relationship between urban sprawl and physical activity, obesity, and morbidity. In Urban ecology, 567-582. New York: Springer.

Goldenberg, R., Z. Kalantari, V. Cvetkovic, U. Mörtberg, B. Deal, and G. Destouni. 2017. Distinction, quantification and mapping of potential and realized supply-demand of flow-dependent ecosystem services. Science of the Total Environment 593: 599-609.

Gren, Å., J. Colding, M. Berghauser-Pont, and L. Marcus. 2019. How smart is smart growth? Examining the environmental validation behind city compaction. Ambio 48: 580-589. https://doi.org/10. 1007/s13280-018-1087-y.

Han, J., X. Meng, X. Zhou, B. Yi, M. Liu, and W.-N. Xiang. 2017. A long-term analysis of urbanization process, landscape change, and carbon sources and sinks: A case study in China's Yangtze River Delta region. Journal of Cleaner Production 141: 1040-1050.

Hankey, S., and J.D. Marshall. 2010. Impacts of urban form on future US passenger-vehicle greenhouse gas emissions. Energy Policy 38: 4880-4887.

Hobbs, T.J., C.R. Neumann, W.S. Meyer, T. Moon, and B.A. Bryan. 2016. Models of reforestation productivity and carbon sequestration for land use and climate change adaptation planning in South Australia. Journal of Environmental Management 181: 279-288.

Hu, Y., G. Jia, C. Pohl, Q. Feng, Y. He, H. Gao, R. Xu, J. van Genderen, et al. 2015. Improved monitoring of urbanization processes in China for regional climate impact assessment. Environmental Earth Sciences 73: 8387-8404.

Irwin, E.G., and N.E. Bockstael. 2007. The evolution of urban sprawl: Evidence of spatial heterogeneity and increasing land fragmentation. Proceedings of the National Academy of Sciences of USA 104: 20672-20677.

Kalantari, Z., S.W. Lyon, L. Folkeson, H.K. French, J. Stolte, P.-E. Jansson, and M. Sassner. 2014. Quantifying the hydrological impact of simulated changes in land use on peak discharge in a small catchment. Science of the Total Environment 466: 741-754.

Kalantari, Z., S. Khoshkar, H. Falk, V. Cvetkovic, and U. Mörtberg. 2017a. Accessibility of water-related cultural ecosystem services through public transport-A model for planning support in the Stockholm region. Sustainability. https://doi.org/10.3390/ su9030346.

Kalantari, Z., C.S.S. Ferreira, R.P.D. Walsh, A.J.D. Ferreira, and G. Destouni. 2017b. Urbanization development under climate change: Hydrological responses in a peri-urban Mediterranean Catchment. Land Degradation and Development 28: 2207-2221.

Kalantari, Z., C.S.S. Ferreira, J. Page, R. Goldenberg, J. Olsson, and G. Destouni. 2019. Meeting sustainable development challenges in growing cities: Coupled social-ecological systems modeling of land use and water changes. Journal of Environmental Management 245: 471-480. https://doi.org/10.1016/j.jenvman. 2019.05.086. 
Kraucunas, I., L. Clarke, J. Dirks, J. Hathaway, M. Hejazi, K. Hibbard, M. Huang, C. Jin, et al. 2015. Investigating the nexus of climate, energy, water, and land at decision-relevant scales: The Platform for Regional Integrated Modeling and Analysis (PRIMA). Climatic Change 129: 573-588.

Larsen, H.N., and E.G. Hertwich. 2010. Implementing carbonfootprint-based calculation tools in municipal greenhouse gas inventories: The case of Norway. Journal of Industrial Ecology 14: 965-977.

Liu, C., and Q. Shen. 2011. An empirical analysis of the influence of urban form on household travel and energy consumption. Computers, Environment and Urban Systems 35: 347-357.

Lubowski, R.N., A.J. Plantinga, and R.N. Stavins. 2006. Land-use change and carbon sinks: Econometric estimation of the carbon sequestration supply function. Journal of Environmental Economics and Management 51: 135-152.

Nejat, P., F. Jomehzadeh, M.M. Taheri, M. Gohari, and M.Z.A. Majid. 2015. A global review of energy consumption, $\mathrm{CO}_{2}$ emissions and policy in the residential sector (with an overview of the top ten $\mathrm{CO}_{2}$ emitting countries). Renewable and Sustainable Energy Reviews 43: 843-862.

Pan, H., and B. Deal. 2019. Reporting on the performance and usability of planning support systems-Towards a common understanding. Applied Spatial Analysis and Policy. https://doi. org/10.1007/s12061-019-09296-5.

Pan, H., B. Deal, Y. Chen, and G. Hewings. 2018a. A reassessment of urban structure and land-use patterns: Distance to CBD or network-based?-Evidence from Chicago. Regional Science and Urban Economics 70: 215-228.

Pan, H., B. Deal, G. Destouni, Y. Zhang, and Z. Kalantari. 2018b. Sociohydrology modeling for complex urban environments in support of integrated land and water resource management practices. Land Degradation and Development 29: 3639-3652.

Pan, H., L. Zhang, C. Cong, B. Deal, and Y. Wang. 2019a. A dynamic and spatially explicit modeling approach to identify the ecosystem service implications of complex urban systems interactions. Ecological Indicators 102: 426-436. https://doi.org/10.1016/j. ecolind.2019.02.059.

Pan, H., J. Page, L. Zhang, S. Chen, C. Cong, G. Destouni, Z. Kalantari, and B. Deal. 2019b. Using comparative socioecological modeling to support Climate Action Planning (CAP). Journal of Cleaner Production 232: 30-42. https://doi. org/10.1016/j.jclepro.2019.05.274.

Pielke, R.A., G. Marland, R.A. Betts, T.N. Chase, J.L. Eastman, J.O. Niles, D.D.S. Niyogi, S.W. Running. 2002. The influence of land-use change and landscape dynamics on the climate system: Relevance to climate-change policy beyond the radiative effect of greenhouse gases. Philosophical Transactions of the Royal Society of London A: Mathematical, Physical and Engineering Sciences 360: 1705-1719.

Searchinger, T., R. Heimlich, R.A. Houghton, F. Dong, A. Elobeid, J. Fabiosa, S. Tokgoz, D. Hayes, et al. 2008. Use of US croplands for biofuels increases greenhouse gases through emissions from land-use change. Science 319: 1238-1240.

Seung-Hwan, Y., C. Jin-Yong, L. Sang-Hyun, O. Yun-Gyeong, and Y.D. Koun. 2013. Climate change impacts on water storage requirements of an agricultural reservoir considering changes in land use and rice growing season in Korea. Agricultural Water Management 117: 43-54.

Song, Y., and G.-J. Knaap. 2004. Measuring urban form: Is Portland winning the war on sprawl? Journal of the American Planning Association 70: 210-225.

Statistics Sweden. 2018. Folkmängd i riket, län och kommuner, 31 december 2018. https://www.scb.se/hitta-statistik/statistik-efteramne/befolkning/befolkningens-sammansattning/ befolkningsstatistik/pong/tabell-och-diagram/kvartals-och- halvarsstatistik-kommun-lan-och-riket/kvartal-4-2018/. Accessed 29 Oct 2019.

Stockholm City. 2016. Strategy for a fossil-fuel free Stockholm by 2040. https://international.stockholm.se/globalassets/rapporter/ strategy-for-a-fossil-fuel-free-stockholm-by-2040.pdf. Accessed 29 Oct 2019.

Tillväxt och regionplaneförvaltningen, TRF. 2017. Regional utvecklingsplan för Stockholm, RUFS 2050. https://www.sll.se/ verksamhet/Regional-utveckling/alla-projekt-inom-regionalutveckling/rufs-2050/. Accessed 19 Oct 2019.

Tillväxt och regionplaneförvaltningen, TRF. 2018. Klimatarbetet $i$ Stockholmsregionen. http://www.rufs.se/globalassets/h.publikationer/2018/klimatarbetet-i-stockholmsregionen.pdf/. Accessed 19 Oct 2019.

Valencia, M.R., I. Davidson-Hunt, and F. Berkes. 2019. Socialecological memory and responses to biodiversity change in a Bribri Community of Costa Rica. Ambio. https://doi.org/10. 1007/s13280-019-01176-z.

Wilson, C.O., and Q. Weng. 2011. Simulating the impacts of future land use and climate changes on surface water quality in the Des Plaines River Watershed, Chicago Metropolitan Statistical Area, Illinois. Science of the Total Environment 409: 4387-4405.

Yang, T., H. Pan, G. Hewings, and Y. Jin. 2019. Understanding urban sub-centers with heterogeneity in agglomeration economiesWhere do emerging commercial establishments locate? Cities 86: $25-36$.

Publisher's Note Springer Nature remains neutral with regard to jurisdictional claims in published maps and institutional affiliations.

\section{AUTHOR BIOGRAPHIES}

Haozhi Pan is an Assistant Professor at School of Design, Shanghai Jiao Tong University, China. His research interests include land-use models and coupled human and natural systems.

Address: School of Design, Shanghai Jiao Tong University, 800 Dongchuan Rd., Shanghai 200240, China.

e-mail: panhaozhi@sjtu.edu.cn

Jessica Page is a PhD Student at Department of Physical Geography, Stockholm University, Sweden. Her research interests include sustainable urban and regional development, and related ecosystem services and water-climate interactions.

Address: Department of Physical Geography and Bolin Centre for Climate Research, Stockholm University, 10691 Stockholm, Sweden e-mail: jessica.page@natgeo.su.se

Le Zhang is a PhD Student at Department of Landscape Architecture, University of Illinois at Urbana-Champaign, USA. His research interests include urban ecosystems and landscape design.

Address: Department of Landscape Architecture, University of Illinois at Urbana-Champaign, Temple Buell Hall 611 Taft Drive, Champaign 61820, IL, USA.

e-mail: lezhang3@illinois.edu

Cong Cong is a PhD Student at Department of Urban and Regional Planning, University of Illinois at Urbana-Champaign, USA. Her research interests include urban transportation and land-use models. Address: Department of Urban and Regional Planning, University of Illinois at Urbana-Champaign, Temple Buell Hall 611 Taft Drive, Champaign 61820, IL, USA.

e-mail: ccong2@illinois.edu

Carla Ferreira is a Post-doctoral Researcher at Center for Natural Resources, Environment and Society (CERNAS), Agrarian School of Coimbra, Polytechnic Institute of Coimbra, Coimbra, Portugal. Her 
research interests include land degradation and its mitigation through nature-based solutions.

Address: Escola Superior Agrária de Coimbra, Bencanta, 3045 Coimbra, Portugal.

e-mail: carla.ssf@gmail.com

Elisie Jonsson is a PhD Student at Department of Physical Geography, Stockholm University, Sweden. Her research interests include carbon sequestration, climate change mitigation, and urban planning. Address: Department of Physical Geography and Bolin Centre for Climate Research, Stockholm University, 10691 Stockholm, Sweden e-mail: elisie.jonsson@natgeo.su.se

Helena Näsström is a Regional Planner at Growth and Regional Planning Management, Region Stockholm, Sweden. Her research interests include regional planning support systems, land-use and transportation models.

Address: Regional Planning, Growth and Regional Planning Management, Stockholm, Sweden.

e-mail: helena.nasstrom@sll.se

Georgia Destouni is a Professor at Department of Physical Geography, Stockholm University, Sweden. Her research interests include water, climate, urbanization, and other land-use and environmental changes and their interactions.
Address: Department of Physical Geography and Bolin Centre for Climate Research, Stockholm University, 10691 Stockholm, Sweden e-mail: georgia.destouni@ natgeo.su.se

Brian Deal is a Professor at Department of Landscape Architecture, University of Illinois at Urbana-Champaign. His research interests include complex urban systems and planning support systems. Address: Department of Landscape Architecture, University of Illinois at Urbana-Champaign, Temple Buell Hall 611 Taft Drive, Champaign 61820, IL, USA.

e-mail: deal@illinois.edu

Zahra Kalantari $(\square)$ is an Associate Professor at Department of Physical Geography, Stockholm University, Sweden. Her special field of research is in the areas of combination of science and application to manage current and mitigate future climate and land-use changes. Address: Department of Physical Geography and Bolin Centre for Climate Research, Stockholm University, 10691 Stockholm, Sweden e-mail: zahra.kalantari@natgeo.su.se 